\title{
Effects of persistent organic pollutants on the thyroid function of the European sea bass (Dicentrarchus labrax) from the Aegean sea, is it an endocrine disruption?
}

\author{
Joseph G. Schnitzler ${ }^{\mathrm{a}, *}$, Emmanuil Koutrakis ${ }^{\mathrm{b}}$, Ursula Siebert ${ }^{\mathrm{c}}$, Jean Pierre Thomé ${ }^{\mathrm{d}}$, Krishna Das ${ }^{\mathrm{a}}$ \\ ${ }^{a}$ Mare Centre, Laboratory for Oceanology B6c, Liège University, Liège, Belgium \\ ${ }^{\mathrm{b}}$ Fisheries Research Institute, National Agricultural Research Foundation, 64007 Nea Peramos, Kavala, Greece \\ ${ }^{\mathrm{c}}$ Research- and Technology Centre Westcoast, Christian-Albrecht-University Kiel, Büsum, Germany \\ ${ }^{\mathrm{d}}$ Laboratory of Animal Ecology and Ecotoxicology B6c, Liège University, Liège, Belgium
}

\begin{abstract}
A B S T R A C T
We evaluated the alterations of organochlorinated compounds such as polychlorobiphenyls (PCB), dichloro-diphenyl-dichloroethylene (DDE) and dichloro-diphenyl-trichloroethane (DDT) on the thyroid in wild and cultured sea bass (Dicentrarchus labrax) at environmental concentrations. These compounds influence the endocrine system of many fish species and are qualified as endocrine disruptors. The thyroid seems to be a target organ. Two alteration endpoints: the thyroid histology and the muscular thyroid hormone concentrations, were used simultaneously.

High concentrations in PCBs and DDT were detected in muscles, supporting the idea that the Mediterranean fauna could be more polluted than the Atlantic fauna. The high abundance of DDE indicates a progressive degradation of remnant DDT load and the absence of new inputs in this area. Aquaculture sea bass shows a significant higher amount of pollutants on fresh weight basis (especially PCBs) in their muscles compared to the wild sea bass. Those differences may be related mainly to the contaminations of diet.

Thyroid parameters vary between wild and aquaculture sea bass, wild sea bass were characterized by higher follicle diameters, epithelial cell heights and muscular $\mathrm{T}_{4}$ concentrations. A significant relationship between persistent organic pollutants (muscular PCBs and DDT concentration) and the different thyroid parameters (diameters of follicles, epithelial cell heights and muscular $\mathrm{T}_{4}$ levels) could be observed, which support the hypothesis that these compounds have an adverse impact on thyroid morphometry and function.
\end{abstract}

(c) 2008 Elsevier Ltd. All rights reserved.

\section{Introduction}

A number of naturally occurring and man-made chemicals are able to interact with the endocrine system of humans and wildlife, which can lead to a disturbance of hormone metabolism or hormone-regulated cellular and physiological processes (Damstra et al., 2002). The thyroid system is a major target of the so called endocrine disrupting chemicals. Today there are around 116 environmental compounds which are suspected to disrupt thyroid function (Howdeshell, 2002). The mechanisms involved in the endocrine disruptor mediated alteration of the thyroid function have been extensively investigated but are still not fully understood. The regulation mechanisms involved in thyroid homeostasis are numerous and complex. As consequence environmental chem-

\footnotetext{
* Corresponding author. Tel.: +32 43663328; fax: +32 43663325

E-mail addresses: joseph.schnitzler@ulg.ac.be (J.G. Schnitzler), manosk@inale.gr (E. Koutrakis), ursula.siebert@ftz-west.uni-kiel.de (U. Siebert), JP.Thome@ulg.ac.be (J.P. Thomé), krishna.das@ulg.ac.be (K. Das).
}

icals can act at many levels in the thyroid system (Ishihara et al., 2003).

Endocrine disrupting chemicals interfere directly with hormone synthesis in the thyroid gland (Ishihara et al., 2003; Brown et al., 2004; Boas et al., 2006). They competitively bound to thyroid hormone binding proteins in blood like transthyretin (TTR) (Wade et al., 2002; Ishihara et al., 2003; Boas et al., 2006), to membrane bound transporters of target cells (Ishihara et al., 2003; Gauger et al., 2004) or to intracellular cytosolic thyroid hormone binding proteins which are thought to act as modulators of nuclear-receptor-mediated transcription (Ishihara et al., 2003; Blanton and Specker, 2007). The endocrine disruptors can also act on metabolic enzymes which activate or inactivate thyroid hormones (Ishihara et al., 2003; Zoeller et al., 2007). Peripheral iodothyronine deiodinases control the conversion of thyroid hormones in different organs and are thus essential in the regulation of levels of biologically active $\mathrm{T}_{3}$ (Boas et al., 2006; Zoeller et al., 2007). Finally those pollutants can disrupt thyroid hormone receptors and accessory proteins which directly control the gene expression through thyroid hormone responsive elements (Ishihara et al., 2003; Blanton 
and Specker, 2007). Beside the direct effects via these sites, indirect effects via the hypothalamus and anterior pituitary gland were also possible (Ishihara et al., 2003; Zoeller et al., 2007).

An endocrine disruption of thyroid function may have severe consequences as thyroid hormones play an important role in the maintenance of a normal physiological status in vertebrates. Thyroid hormones assist in control of different physiological functions according to the development state of embryo, larva, juvenile and adult fish (Janz, 2000). In fish, thyroid status is positively correlated to reproductive status, whereas a seasonal rise in thyroid hormones coincident with gonadal maturation and reproduction has generally been observed. During ovarian maturation, thyroid hormones accumulates in the developing oocytes where they play a significant role in fish embryogenesis (Power et al., 2001; Yamano, 2005). Small thyroid follicles appear first at early stages of the larval period, then the follicles increases gradually in number and size. These small follicles are able to produce thyroid hormones which are detectable in larval fish in low concentrations (Yamano, 2005). During this phase the thyroid hormones intervene in the transformation of larvae into juveniles (Power et al., 2001).

In adult fish, thyroid hormones are of primary importance in the regulation of such fundamental physiological processes as growth, nutrient utilization, and reproduction, but the exact mode of action is unknown. Fish grow faster and are healthier when the thyroid hormone levels are high (Power et al., 2001; Yamano, 2005), which point out an economic outlet of this problematic in fishery and aquaculture.

Polychlorinated biphenyls (PCBs) and insecticides (like DDT and its metabolites), have been shown to alter thyroid hormone levels in experimental animals (Collins and Capen, 1980a, 1980b; Brouwer et al., 1989; Fowles et al., 1997; Hallgren and Darnerud, 2002). The aim of this paper is to evaluate if these alterations of the thyroid function are also observable in wild and cultured fish at environmental conditions. The European sea bass (Dicentrarchus labrax), is the top predator of a simple food web, it is commonly found in European coastal waters, its biology is well documented (Pickett and Pawson, 1994; Loizeau et al., 2001) and it is an important commercial species, also important from a human health view point.

To achieve this goal the concentrations of organochlorinated compounds were measured in wild and cultured specimens of $D$. labrax, and their effects on the thyroid function using simultaneously two thyroid endpoints were evaluated. The first is the thyroid histomorphometry which consist in a microscopically quantification of the diameter of follicles and the epithelial cell heights and the second is an analysis of muscular thyroid hormone concentrations. The combined analysis of histological and hormonal biomarkers allows a better estimation of the thyroid function status. The possible impact of the levels in PCBs and DDTs on the thyroid gland will be studied via a multivariate analysis.

\section{Methods}

\subsection{Study site}

Forty-six D. labrax specimens have been obtained during a sampling mission in the North Aegean (Eastern Mediterranean, Greece) which took place in February 2006. The fish used in this study were caught in the northern part of the Aegean Sea, fifteen of which were caught in the Stymonikos Gulf and the other thirty-one came from an cage fish farm situated in the isle of Thassos.

Strymonikos Gulf, occupies an area of $540 \mathrm{~km}^{2}$ and its coast has a total length of $70 \mathrm{~km}$. The Strymon River, found at the north of the Gulf, coming from Bulgaria with a catchment area of $17.130 \mathrm{~km}^{2}$, and the Richios River at the west, constitute the main sources of fresh water, nutrients and pollution (domestic and agricultural pollutants) in this area (Stamatis et al., 2002; Kallianiotis et al., 2004). The Gulf is one of the most important nursery and fishing grounds for pelagic species of the North Aegean Sea (Sylaios et al., 1999). This area includes the most variable and spectacular insular, coastal and marine landscapes, as well as flora and fauna (Koutrakis et al., 2000). The gulf has a heavy pollution impact from land based sources, which includes fertilisers and pesticides from agriculture, untreated waste water from cities, and industrial waste from chemical plants are some of the localised threats, while intense oil tanker traffic and high fishing effort are widespread in this area (Dassenakis, 2000).

The isle of Thassos is located in the northern Aegean sea approximately $7 \mathrm{~km}$ from the mainland and $20 \mathrm{~km}$ south-east of Kavala. It has a total coastal length of $115 \mathrm{~km}$ and its total land surface is $378,84 \mathrm{~km}^{2}$. The cage fish farm is situated at the north part of the island and is the only cage farm in the Kavala Prefecture. It has a total yearly capacity of about $70 \mathrm{t}$ and its main production consists of Gild-head sea bream and European sea bass. The unit is positioned in a closed and windless bay with a depth of $12 \mathrm{~m}$. In addition to its other production processes there is also a small hatchery for sea species (mainly European sea bass), witch covers its needs. The surrounding waters of both the unit and the island in general are relatively unpolluted (Kallianiotis et al., 2000).

\subsection{Sampling of the different tissues}

The fish were killed in ice water and stored on ice till their arrival at the Institute where they were immediately dissected. The length and the weight of each fish were measured. The lower jaw was removed from each animal and immersed in Bouin's fixative. Approximately $30 \mathrm{~g}$ skeletal muscle was excised from the area behind the head, dorsal to the lateral line and anterior to the dorsal fin. The muscle samples were stored at $-70{ }^{\circ} \mathrm{C}$ until analysis.

\subsection{Thyroid histomorphometric analysis}

The thyroid tissues enclosed in the lower jaw parts were stored in Bouin's fixative. The tissue was then decalcified in $5 \%$ formic acid and $5 \%$ formaldehyde for a day and transferred into a sodium sulphate solution for one day. The tissues were dehydrated in a graded series of ethanol before being embedded in paraffin wax. The paraffin blocks were longitudinally sectioned $(8 \mu \mathrm{m})$ through all the thyroid tissue (Zhou et al., 2000).

The hematoxylin-eosin stain and the Van Gieson stain method were used for the microscopically diagnostic study of the histological samples (Zhou et al., 2000). These staining methods were perfectly suitable for this kind of study, since the follicles and the epithelial cells were clearly designable and different measurements could be taken.

Thyroid histomorphometry was measured using DP-Soft ${ }^{\circledR}$ software (version 3.2 Soft Imaging Systems $\mathrm{Gmbh}$ ) with a digital camera (Olympus C-4040) connected to a light microscope (Olympus Statif CX 41). DP-Soft is a basic image software for microscopy analysis, it permits the acquisition, the archivation and different measurements of the images. For the histomorphological analysis, images of ten randomly selected visual fields in the microscope, with a magnification 200 of each section, were observed.

The images showed a vision field of $633.1 \mu \mathrm{m}$ large and $474.8 \mu \mathrm{m}$ height. The different measurements in the thyroid tissue were determined by surrounding the contours of the follicles in the tissue. The follicle area and size and the epithelial cell height was thus interactively measured in each vision field. The calculation of the mean value used for statistical analyses was carried out by using 10 values per individual. 


\subsection{Organochlorine compound analysis}

All solvents were of pesticide grade; $n$-hexane and acetone (Burdick \& Jackson brand) were purchased from Fluka (Buchs, Switzerland). The Mirex (Dodecachloropentacyclo-[5.3.0.0.0.0]decane) used as internal standard, the pure PCB congeners (IUPAC Nos. $28,44,52,66,70,87,95,101,105,110,118,128,138,149,153$, $156,170,180,183,187,194,195,206$, and 209) and the congener used as surrogate (IUPAC No. 112), were obtained from Ultra Scientific ${ }^{\circledR}$ and Dr. Ehrenstorfer ${ }^{\circledR}$. All other chemicals used were of analytical grade.

Muscle samples were lyophilized over $20 \mathrm{~h}$ and dry matter was determined gravimetrically. The lipids were extracted using an accelerated solvent extractor (ASE) (Dionex ASE 2000, Dionex Corporation). A $650-750 \mathrm{mg}$ sample of lyophilized muscle with $0.5 \mathrm{~g}$ of anhydrous sodium sulphate was extracted 3 times with a mixture of hexane, dichloromethane and methanol (5:2:1, v:v:v) at $80^{\circ} \mathrm{C}$ and under a pressure of 1500 Psi. The solvent with the extracted fat was collected in pre-weighed vials and was evaporated at $40{ }^{\circ} \mathrm{C}$ under nitrogen flow (Turbovap LV Zymark). The fat content of muscle samples ('hexane-extracted fat') was determined gravimetrically. Lipids were then dissolved into $3 \mathrm{ml}$ of hexane and collected into a test tube. The mixture was homogenized by vortexing during $1 \mathrm{~min}$.

All prepared samples were then purified by acid and Florisil clean-ups. A $2 \mathrm{ml}$ volume of sulphuric acid mixture (fuming sulphuric acid 30\% and concentrated sulphuric acid 95\%, 1:3, v:v) was added to the sample and the mixture was homogenized by vortexing before being centrifuged for $3 \mathrm{~min}$ at $1810 \mathrm{~g}$ at $10^{\circ} \mathrm{C}$ (Jouan). The organic phase was transferred to another tube and the acidic phase was extracted with $3 \mathrm{ml}$ of hexane, vortexed and centrifuged for another $3 \mathrm{~min}$. The organic phases were pooled and reduced to $1 \mathrm{ml}$ under a nitrogen flow. The second clean-up was performed with Florisil ${ }^{\circledR}$ solid phase cartridges (Supelco, EnviFlorisil). The cartridges were first conditioned with $5 \mathrm{ml}$ of acetone, $5 \mathrm{ml}$ of an acetone-hexane mixture (50:50, v:v) and $12 \mathrm{ml}$ of hexane, successively. The sample was then added at the top of the column. Polar molecules were retained on the Florisil® (magnesiumsilicate mixture). The test tubes containing the sample were rinsed with $3 \mathrm{ml}$ of hexane and added to the cartridge. Another $3 \mathrm{ml}$ of hexane were finally directly added to the column. The eluate was then evaporated just to dryness under a gentle nitrogen flow.

The dried residue of muscle samples was reconstituted with $125 \mu \mathrm{l}$ of hexane and $125 \mu \mathrm{l}$ of Mirex $\left(100 \mathrm{pg}^{-1}\right)$. The purified extracts were then analysed by gas chromatography using a Thermo Quest Trace 2000 gas chromatograph equipped with a $63 \mathrm{Ni}$ ECD detector (Thermo Quest, Trace 2000) and an automatic injector. From 1 to $5 \mu$ of each purified extract was injected by means of a cold 'on column' injector. PCB congeners were separated on a $30 \mathrm{~m} \times 0.25 \mathrm{~mm}(0.25 \mu \mathrm{m}$ film $)$ RESTEK RXI-5 ms capillary column (Bellefonte, USA). The temperature program was as follows: $2 \mathrm{~min}$ at $60^{\circ} \mathrm{C}$, gradual heating from 60 to $140{ }^{\circ} \mathrm{C}$ at the rate of $20^{\circ} \mathrm{C} \mathrm{min}{ }^{-1}, 3 \mathrm{~min}$ at $140^{\circ} \mathrm{C}$, gradual heating from 140 to $270{ }^{\circ} \mathrm{C}$ at the rate of $25^{\circ} \mathrm{C} \mathrm{min}-1$ and $12 \mathrm{~min}$ at $270{ }^{\circ} \mathrm{C}$. The carrier gas was hydrogen with a flow rate of $4 \mathrm{ml} \mathrm{min}^{-1}$ and a pressure of $130 \mathrm{kPa}$, and the make-up gas was Ar:CH4 (95:5) at a flow rate of $30 \mathrm{ml} \mathrm{min}^{-1}$. The injector was at ambient temperature and the detector was kept at $300^{\circ} \mathrm{C}$. PCBs were identified according to their retention times. Twenty-seven congeners, mostly present in Aroclor 1242, 1254 and 1260 mixtures, were measured (IUPAC 28, 44, $52,66+95,70,87,101,105,110+77,118,126,128,138,149$, $153,156,169,170,180,183,187,194,195,206$, and 209) and the $p^{\prime} p$-DDT and $p^{\prime} p$-DDE. The + sign indicates that these two congeners are not separated. Data were recorded using Chrom-Card 1.19 software. Quantification was performed by comparison with external standards of the 27 pure $\mathrm{PCB}$ components in a certified calibration mixture (Ultra Scientific and Dr. Ehrenstorfer $\left.{ }^{\circledR}\right)$, using a linear calibration curve for each PCB congener whose concentration ranged from 2 to $100 \mathrm{pg} \mu \mathrm{l}^{-1}$. PCB concentrations are expressed as the sum of the congeners measured.

Blanks were run with each sample series to control the clean-up procedures. Blanks were also used to control lyophilization and ASE steps. For each sample, a quality control (QC) was also analysed in parallel. Milk cream enriched with a defined concentration of PCBs was used as a QC for analysis. The PCB recovery was calculated on the basis of the concentration of the surrogate standard (IUPAC 112 , Dr. Ehrenstorfer $\left.{ }^{\circledR}\right)\left(50 \mathrm{pg} \mu \mathrm{l}^{-1}\right)$. It was added to the sample at the beginning of the clean-up for muscle samples. All results were corrected to obtain $100 \%$ recovery. However, the results of the PCB analyses were accepted only if the recoveries were between $70 \%$ and $130 \%$.

\subsection{Radio-immuno-assay}

The iodothyronines were extracted from the muscle sample using procedures adapted from Parker (1988). The muscle was rinsed with $\mathrm{NaCl}$ solution $(0.87 \%)$, minced with scissors and homogenized using a tissue grinder ( $60 \mathrm{~s}, 22,000 \mathrm{rpm}$ ) with $3 \mathrm{ml}$ ice cold $100 \%$ ethanol containing $1 \mathrm{mM}$ 6-n-Propyl-2-thiouracil. All the above procedures were performed on ice. After $15 \mathrm{~min}$, the mixture was centrifuged at $1500 \mathrm{~g}$ for $10 \mathrm{~min}$ at $4{ }^{\circ} \mathrm{C}$ and the supernatant was transferred to evaporations. The pellets were washed twice with $2 \mathrm{ml} 100 \%$ ethanol by resuspension followed by centrifugation. The pooled supernatant was evaporated at $40{ }^{\circ} \mathrm{C}$ to dryness. The dried sample was stored at $0{ }^{\circ} \mathrm{C}$ until thyroid hormone content was assayed.

For the radioimmunoassay (RIA), the samples were re-suspended in $250 \mu \mathrm{l} 95 \%$ ethanol and $250 \mu \mathrm{l} 0.11 \mathrm{M}$ sodium barbital ( $\mathrm{pH}$ 8.6). Each $500 \mu \mathrm{l}$ sample was vortexed for $15 \mathrm{~s}$ after each solution was added. The sample was transferred into an eppendorf snap cap vial and centrifuged at $3000 \mathrm{rpm}$ for $10 \mathrm{~min}$ at $4{ }^{\circ} \mathrm{C}$. Each sample was assayed in duplicate for $\mathrm{T}_{4}$ content and for $\mathrm{T}_{3}$ content. In this procedure $25 \mu \mathrm{l}$ of the sample and $1 \mathrm{ml}$ of radiolabelled thyroid hormone were added to antibody coated test tubes. The thyroid hormones compete for a fixed time $\left(1 \mathrm{~h}\right.$ at $\left.37^{\circ} \mathrm{C}\right)$ for sites on the specific antibodies. Since the antibody is immobilized on the wall of the test tubes, simply decanting the supernatant suffices to terminate the competition and to isolate the antibody-bound fraction of the radiolabelled thyroid hormones. Counting the tube in a gamma counter then yields a number, which converts by way of calibration curve to a measure of the thyroid hormones present in the fish sample. The kit was used according to manufactures instruction and chosen for well described affinities for fish thyroid hormones (Scholtz et al., 1992; Raine, 1998; Plate et al., 2002; Jenssen et al., 2004).

A computer program, contained in the counter, automatically determined the relative percent bound to each standard concentration and plotted a log-logit graph of the standard curve (\% bound vs standard concentrations). The program then examined the percent for each unknown sample and interpolated the concentration of the sample from the standard curve graph. Total thyroid hormone content of each individual fish sample was determined by multiplying the hormone content of $25 \mu \mathrm{l}$ subsample by 20 (500 $\mu \mathrm{l}$ total sample volume $/ 25 \mu$ l subsample tested for TH content) and converting this concentration to total ng/sample. This number was divided by the weight of the extracted muscle to provide the hormone concentration of each fish in $\mathrm{ng} \mathrm{g}^{-1}$ body weight (Scholtz et al., 1992).

To determine the efficiency of the extraction process in recovering thyroid hormones as well as transfer of samples into different types of tubes, a recovery analysis was employed. Unlabelled 
thyroid hormone was added to the minced muscles prior to homogenization. Replicates tubes each were spiked with $0,1,4,10,16$, and $24 \mu \mathrm{g} \mathrm{dL}^{-1}$ unlabelled $\mathrm{T}_{4}$ and $0,20,50,100,200$, and $600 \mathrm{ng} \mathrm{dL}^{-1}$ unlabelled $\mathrm{T}_{3}$. The samples were then subjected to the same homogenization, extraction, reconstitution and RIA assay procedures as the unknown and standard curve samples. The percentage of thyroid hormone recovered from each spiked tube was calculated. These quality assurance procedures and recovery determinations were also performed in the study of Scholtz et al. (1992) on the Kokanee salmon (Oncorhynchus nerka) (Scholtz et al., 1992).

\subsection{Statistical analysis}

The relationships between thyroid parameters (follicle histomorphometry and thyroid hormone concentrations) and toxicological data were analysed in two steps. First, a correlation-based principal component analysis (PCA) was performed to reduce the 16 original $\mathrm{PCB}$ congener variables in order to avoid misleading results due to correlating independent variables ('multi-collinearity') in subsequent analysis. Thereafter a Spearman correlation test, with the three factor scores revealed by the PCA as independent variables and thyroid parameters as dependent variable, was applied. Results were considered significant when $p<0.05$. Contaminant values were log-transformed to achieve homogeneity of variances and normal distribution. The non-parametric Mann-Whitney $U$-test was used to compare differences among sexes and the sample origin (wild or aquaculture). Statistical analysis of the data was performed using Statistica ${ }^{\circledR}$ software (Statsoft Inc., version 7.1).

\section{Results}

\subsection{Thyroid histology of the European sea bass}

The structure of the teleost thyroid, although similar to that of higher vertebrates, differs in its lack of a discrete organization.
The thyroid tissue of the European sea bass consists of glandular follicles scattered around the ventral aorta and bronchial arteries that supply the gills (Fig. 1A). The follicle consists of an outer layer of thyroid epithelium that surrounds an inner lumen filled with colloid. Colloid contains a reserve of the protein-bound form of the thyroid hormones (Fig. 1B). The surrounding epithelial cells are either flattened, cuboidal, or columnar, depending on their activity. In light microscopy irregular or oval follicular lumen were seen surrounded by follicular epithelial cells (Fig. 1C). Stratified follicular epithelial cells were often invaginated into the follicular lumen. The nucleus of the gland cells were spheroidal, centrally situated, poor in chromatin and contain one or more nucleoli. The use of the Van Gieson method which permits to differentiate the connective tissue brought no further information of organisation (Fig. 1D). The thyroid tissue is composed of isolated thyroid follicles intermixed with the well vascularized connective tissue of the lower jaw.

\subsection{Thyroid histomorphometric analysis}

Wild caught specimens were found to have larger follicles than those from the aquaculture unit as their follicles have significant higher surface and diameter (Mann-Whitney; $p<0.05$; Table 1 ). Beside this wild sea bass showed thicker epithelium compared to those coming from aquaculture (Mann-Whitney; $p<0.05$; Table $1)$. No differences in histological thyroid parameters could be revealed by Mann-Whitney test between sexes $(p>0.05)$. No significant relationship of length and weight on the histological thyroid parameters could be showed in our sampling (Spearman correlation, $p>0.05$ ). All individuals were regrouped for the further statistical analysis.

\subsection{Dosage of thyroid hormones in muscle using radio-immuno-assay}

Results of the recovery data from thyroid hormone spiked muscle indicate that percent recovery was $92.6 \%$ for $\mathrm{T}_{3}$ and $92.4 \%$ for $\mathrm{T}_{4}$.

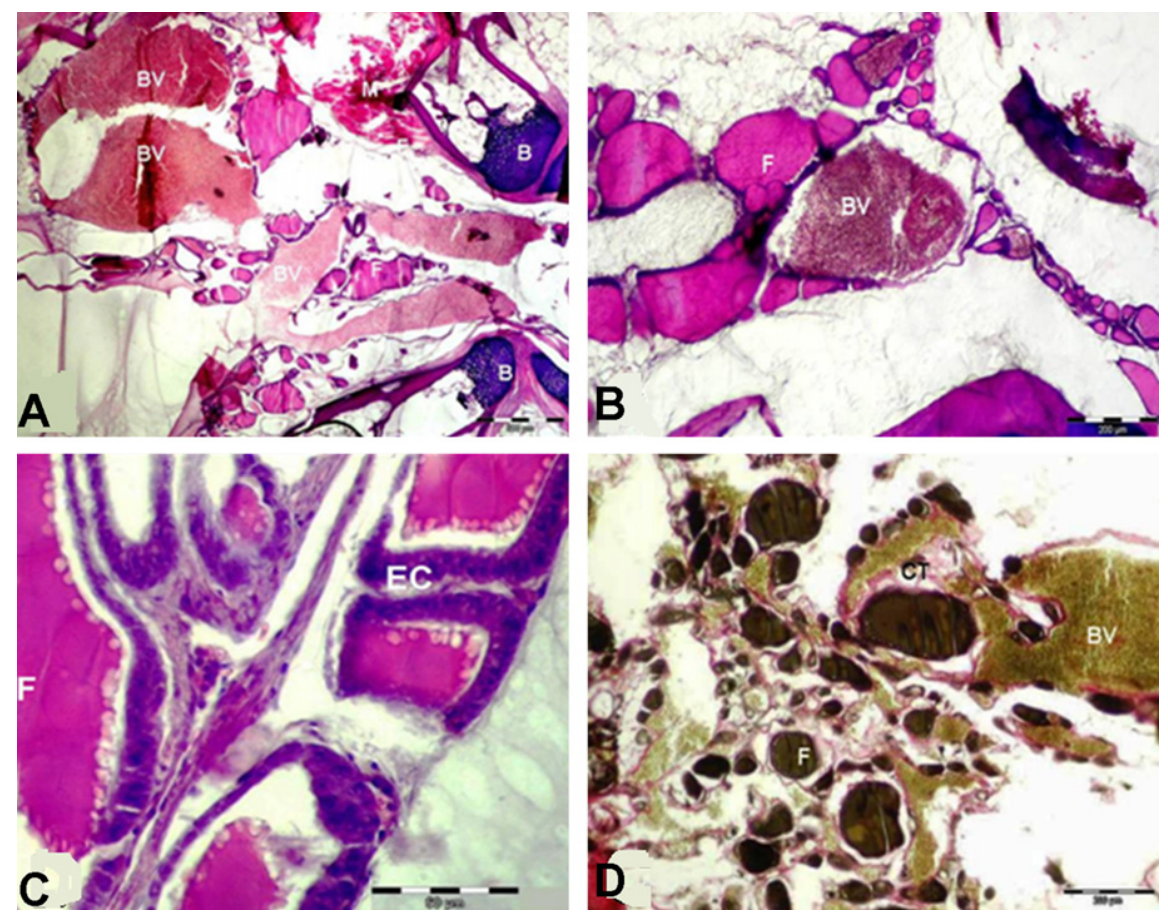

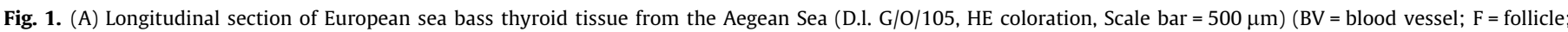

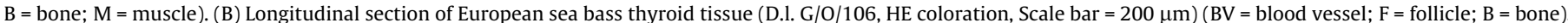

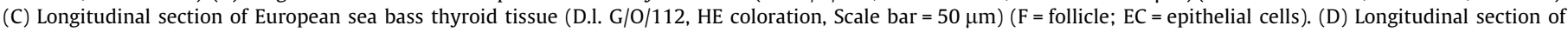
European sea bass thyroid tissue (D.l. G/A/217, Van Gieson method, Scale bar $=200 \mu \mathrm{m})(\mathrm{BV}=$ blood vessel; $\mathrm{F}=$ follicle; $\mathrm{CT}=$ connective tissue). 
Table 1

Histomorphometric analysis, thyroid hormone levels, lipid proportion, mean contamination levels of the 7 ICES PCBs, the 27 measured PCBs and of the pesticides ( $p p^{\prime}-$ DDT, $p p^{\prime}$-DDE, $p p^{\prime}$-DDD) in the white muscle of European sea bass collected in the Aegean Sea from wild and from aquaculture and their food pellets

\begin{tabular}{|c|c|c|c|c|c|c|}
\hline \multirow{2}{*}{\multicolumn{2}{|c|}{$n$}} & \multicolumn{2}{|l|}{ Wild } & \multicolumn{2}{|l|}{ Aquaculture } & \multirow[t]{2}{*}{$p$-value } \\
\hline & & 13 & & 28 & & \\
\hline \multicolumn{2}{|c|}{ Follicle area $\left(\mu \mathrm{m}^{2}\right)$} & $\begin{array}{l}3319= \\
3140 \\
1533-\end{array}$ & $\begin{array}{l}1609 \\
8243\end{array}$ & $\begin{array}{l}2452 \pm 1540 \\
1973 \\
1045-8147\end{array}$ & & 0.006 \\
\hline \multicolumn{2}{|c|}{ Follicle diameter $(\mu \mathrm{m})$} & & $48-99$ & $\begin{array}{l}56 \pm 15 \\
52 \\
39-108\end{array}$ & & 0.002 \\
\hline \multicolumn{2}{|c|}{ Cell height $(\mu \mathrm{m})$} & \multicolumn{2}{|l|}{$\begin{array}{l}7 \pm 1 \\
7 \\
4-9\end{array}$} & $\begin{array}{l}4 \pm 1 \\
4 \\
3-6\end{array}$ & & $<0.001$ \\
\hline \multicolumn{2}{|c|}{$\mathrm{T}_{3}\left(\mathrm{ng} \mathrm{g}^{-1}\right)$} & \multicolumn{2}{|c|}{$\begin{array}{l}n=13 \\
0.21 \pm 0.11 \\
0.18 \\
0.12-0.51\end{array}$} & $\begin{array}{l}n=17 \\
0.26 \pm 0.17 \\
0.23 \\
0.06-0.75\end{array}$ & & 0.509 \\
\hline \multicolumn{2}{|c|}{$\mathrm{T}_{4}\left(\mathrm{ng} \mathrm{g}^{-1}\right)$} & \multicolumn{2}{|c|}{$\begin{array}{l}n=3 \\
11.44 \pm 3.17 \\
11.55 \\
8.22-14.56\end{array}$} & $\begin{array}{l}n=19 \\
8.07 \pm 4.04 \\
6.54 \\
3.99-18.39\end{array}$ & & 0.132 \\
\hline \multicolumn{2}{|c|}{$\mathrm{T}_{3} / \mathrm{T}_{4}\left(\mathrm{ng} \mathrm{g}^{-1}\right)$} & \multicolumn{2}{|c|}{$\begin{array}{l}n=2 \\
0.012 \pm 0.005 \\
0.012 \\
0.009-0.016\end{array}$} & $\begin{array}{l}n=11 \\
0.033 \pm 0.018 \\
0.03 \\
0.009-0.070\end{array}$ & & 0.103 \\
\hline \multicolumn{2}{|c|}{ Lipid proportion (\%) } & \multicolumn{2}{|c|}{$\begin{array}{l}n=13 \\
0.8 \pm 0.29 \\
0.8 \\
0.39-1.27\end{array}$} & $\begin{array}{l}n=17 \\
1.9 \pm 0.65 \\
1.8 \\
0.95-3.02\end{array}$ & & $<0.001$ \\
\hline & $\begin{array}{l}\text { Fresh } \\
\text { weight }\end{array}$ & $\begin{array}{l}\text { Lipid } \\
\text { weight }\end{array}$ & $\begin{array}{l}\text { Fresh } \\
\text { weight }\end{array}$ & $\begin{array}{l}\text { Lipid } \\
\text { weight }\end{array}$ & $\begin{array}{l}\text { Fresh } \\
\text { weight }\end{array}$ & $\begin{array}{l}\text { Lipid } \\
\text { weight }\end{array}$ \\
\hline $\begin{array}{l}\text { Sum } 7 \\
\text { ICES }\end{array}$ & $\begin{array}{l}n=12 \\
2.02 \pm 0.95 \\
1.67 \\
1.04-3.73\end{array}$ & $\begin{array}{l}n=12 \\
251.2 \pm 165.8 \\
225.9 \\
62.3-717.5\end{array}$ & $\begin{array}{l}n=16 \\
5.62 \pm 1.82 \\
4.59 \\
3.64-8.66\end{array}$ & $\begin{array}{l}n=16 \\
298.2 \pm 90.1 \\
261.4 \\
205.7-535.7\end{array}$ & $<0.001$ & 0.09 \\
\hline $\begin{array}{c}\text { Sum } 27 \\
\text { PCB }\end{array}$ & $\begin{array}{l}n=12 \\
5.53 \pm 1.40 \\
5.25 \\
3.43-7.92\end{array}$ & $\begin{array}{l}n=12 \\
746.5 \pm 309.1 \\
723.1 \\
262.9-1369.0\end{array}$ & $\begin{array}{l}n=16 \\
8.91 \pm 2.53 \\
8.04 \\
6.21-12.77\end{array}$ & $\begin{array}{l}n=16 \\
514.0 \pm 142.2 \\
467.0 \\
364.7-759.9\end{array}$ & $<0.001$ & 0.018 \\
\hline$p p^{\prime}-\mathrm{DDT}$ & $\begin{array}{l}n=12 \\
0.30 \pm 0.22 \\
0.22 \\
0.04-0.71\end{array}$ & $\begin{array}{l}n=12 \\
34.3 \pm 28.8 \\
23.22 \\
6.57-98.4\end{array}$ & $\begin{array}{l}n=16 \\
0.38 \pm 0.14 \\
0.33 \\
0.17-0.63\end{array}$ & $\begin{array}{l}n=16 \\
30.0 \pm 40.0 \\
19.3 \\
13.7-183.0\end{array}$ & 0.273 & 0.414 \\
\hline$p p^{\prime}-\mathrm{DDE}$ & $\begin{array}{l}n=12 \\
4.53 \pm 2.57 \\
4.31 \\
1.80-11.24\end{array}$ & $\begin{array}{l}n=12 \\
521.6 \pm 271.2 \\
486.2 \\
111.2-1003.9\end{array}$ & $\begin{array}{l}n=16 \\
2.01 \pm 0.81 \\
1.66 \\
1.01-3.89\end{array}$ & $\begin{array}{l}n=16 \\
109.5 \pm 42.2 \\
97.6 \\
75.5-222.6\end{array}$ & 0.001 & $<0.001$ \\
\hline$p p^{\prime}-\mathrm{DDD}$ & $\begin{array}{l}n=12 \\
0.52 \pm 0.45 \\
0.35 \\
0.12-1.72\end{array}$ & $\begin{array}{l}n=12 \\
59.0 \pm 47.8 \\
39.1 \\
10.1-153.7\end{array}$ & $\begin{array}{l}n=16 \\
0.75 \pm 0.29 \\
0.63 \\
0.37-1.25\end{array}$ & $\begin{array}{l}n=16 \\
40.8 \pm 13.2 \\
39.3 \\
24.7-74.1\end{array}$ & 0.123 & 0.884 \\
\hline
\end{tabular}

The concentrations are given in $\mathrm{ng} \mathrm{g}^{-1}$ lipid weight and fresh weight. (mean \pm standard deviation, (median) and min-max) followed by a MannWhitney test to reveal potential differences in parameters (Significant $p$-values are in bold).

These recovery values were similar to those reported by other researchers; e.g., Kobuke et al. (1987) reported $83 \%$ in coho salmon eggs. The thyroid hormone content of $5 \mathrm{~g}$ of muscle of each fish sample was determined by multiplying the thyroid hormone content of $25 \mu \mathrm{l}$ subsample by 20 ( $500 \mu$ l total sample volume divided by $25 \mu$ subsample tested for hormone content) and dividing by the weight of the excised muscle of each fish (Table 1 ). Some samples were below the limit of detection have been ignored in the following statistical analysis. No statistical differences of these results in relation to the origin or sex could be revealed by Mann-Whitney tests. No significant relationship of length and weight on the muscular thyroid hormone content was found in the specimens used. (Spearman correlation, $p>0.05$ ). This permitted the grouping of all the sampled animals for the following statistical analysis.

\subsection{Organochlorine compound analysis}

Lipid proportion in the muscles of the European sea bass from aquaculture and from wild ranged around from $0.4 \%$ to $3 \%$ of the wet weight. Sea bass from aquaculture had a significant higher lipid content in their muscles than those from wild (Mann-Whitney; $p<0.05$; Table 1). From the 27 PCBs congeners that were analysed only 16 were detected in all the fish (IUPAC 28, 52, 44, 70, $66+95$, $101,112,110+77,149,118,143,153,138$, and 180), the others have been ignored in the following principal component analysis. The 7 ICES (International Council for the Exploration of the Sea) PCBs (IUPAC 28, 52, 101, 118, 138, 153 and 180), the major congeners and most predominant used in the different commercial mixtures of PCBs, represent around $40-60 \%$ of all the found congeners according to the origin of the samples (Table 1).

Males and females were regrouped for the analysis because no significant difference could be detected (Mann-Whitney; $p>0.05$ ). The wild sea bass had a significant higher total PCBs and $p p^{\prime}$-DDE lipid-normalized concentrations in their muscles than those from aquaculture. No significant differences were observed in the lipid-normalized concentrations of the 7 ICES PCBs, the $p p^{\prime}$-DDT and the $p p^{\prime}$-DDD between wild and aquaculture sea bass (Table 1 ). The comparison of the fresh weight concentrations reveal meanwhile that aquaculture sea bass had a significant higher concentration of the 7 ICES PCBs and total PCBs whereas wild sea bass showed the highest $p p^{\prime}$-DDE concentrations. No significant differences were observed in the fresh weight concentrations of the $p p^{\prime}$-DDT and the $p p^{\prime}$-DDD between wild and aquaculture sea bass (Table 1). The following 7 ICES PCBs were found in wild sea bass in decreasing importance: $153>138>28>101>180>$ $52>118$ and in aquaculture sea bass: $153>101>138>118>52$ $>180>28$. The pattern of aquaculture sea bass does not reflect specially the contamination pattern of their food: $153>138>52>180>101>118>28$.

\subsection{Relationship between thyroid parameters and $P C B$ contamination}

It is well known that PCB congeners may interact each to other, their effect can be antagonized or exhausted by the presence of the others congeners. The fresh weight pollutant concentrations have been used for this analysis as the thyroid hormone concentrations are not related to lipids and are also expressed in fresh weight concentrations. A principal component analysis permitted us to reduce the 16 PCB variables to 3 principal components. The three components represent $80 \%$ of the total variance (Table 2 ). The first component represent almost all the $\mathrm{PCB}$ congeners with a high degree of chlorination (hepta-, hexa- and pentachlorobiphenyls), whereas the second component represent a mixture of PCB congeners of different degree of chlorination and the third component represents mostly the PCB 52 (Table 2). Spearman correlation tests were used to test the effects of the different components on the thyroid parameters. A significant relationship could be observed between the follicle diameter, the epithelial cell height, the $T_{3} / T_{4}$ ratio and the first principal component. No significant relationship could be observed with the second and third component (Table 2). 
Table 2

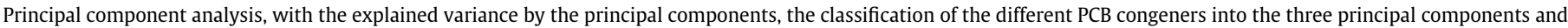
the results of the multivariate Spearman correlation tests (Significant $p$-values are in bold)

\begin{tabular}{|c|c|c|c|c|c|c|}
\hline & \multicolumn{3}{|l|}{ Lipid weight } & \multicolumn{3}{|l|}{ Fresh weight } \\
\hline & Fact. 1 & Fact. 2 & Fact. 3 & Fact. 1 & Fact. 2 & Fact. 3 \\
\hline$\%$ of total variance & 39.7 & 31.3 & 8.9 & 54.7 & 15.6 & 10.3 \\
\hline Cumulative variance\% & 39.7 & 71 & 79.9 & 54.7 & 70.3 & 80.6 \\
\hline 44 & 0.28 & -0.57 & 0.36 & -0.06 & -0.36 & -0.65 \\
\hline 70 & -0.21 & -0.86 & -0.36 & -0.49 & 0.54 & -0.62 \\
\hline $66+95$ & -0.71 & -0.47 & -0.32 & -0.73 & 0.59 & -0.28 \\
\hline 101 & -0.96 & 0.15 & 0.07 & -0.93 & 0.02 & 0.09 \\
\hline 112 & 0.48 & -0.81 & -0.02 & 0.73 & -0.35 & -0.29 \\
\hline $110+77$ & -0.9 & -0.09 & 0.1 & -0.93 & -0.18 & 0.03 \\
\hline 118 & -0.9 & 0.22 & 0.12 & -0.93 & -0.18 & 0.22 \\
\hline 143 & 0.15 & -0.86 & 0.13 & -0.14 & -0.80 & -0.28 \\
\hline 153 & -0.81 & -0.41 & 0.07 & -0.95 & -0.22 & 0.05 \\
\hline 138 & -0.69 & -0.67 & -0.11 & -0.90 & -0.23 & -0.06 \\
\hline 180 & -0.68 & -0.13 & 0.09 & -0.62 & -0.13 & 0.12 \\
\hline Diameter $(\mu \mathrm{m})$ & $\begin{array}{l}R_{\mathrm{S}}=0.495 \\
N=21 \\
\boldsymbol{p}=\mathbf{0 . 0 2 3}\end{array}$ & $\begin{array}{l}R_{\mathrm{S}}=-0.112 \\
N=21 \\
\quad p=0.630\end{array}$ & $\begin{array}{c}R_{\mathrm{S}}=0.069 \\
N=21 \\
p=0.767\end{array}$ & $\begin{array}{l}R_{\mathrm{S}}=0.390 \\
N=21 \\
\boldsymbol{p}=\mathbf{0 . 0 4 9}\end{array}$ & $\begin{array}{l}R_{\mathrm{S}}=-0.109 \\
N=21 \\
\quad p=0.596\end{array}$ & $\begin{array}{l}R_{\mathrm{S}}=0.032 \\
N=21 \\
p=0.877\end{array}$ \\
\hline Cell height $(\mu \mathrm{m})$ & $\begin{array}{l}R_{\mathrm{S}}=0.527 \\
N=21 \\
\boldsymbol{p}=\mathbf{0 . 0 1 4}\end{array}$ & $\begin{array}{l}R_{\mathrm{S}}=-0.212 \\
N=21 \\
\quad p=0.357\end{array}$ & $\begin{array}{c}R_{\mathrm{S}}=-0.358 \\
N=21 \\
p=0.111\end{array}$ & $\begin{array}{l}R_{\mathrm{S}}=0.536 \\
N=21 \\
\boldsymbol{p}=\mathbf{0 . 0 0 5}\end{array}$ & $\begin{array}{l}R_{\mathrm{S}}=-0.387 \\
N=21 \\
\quad p=0.051\end{array}$ & $\begin{array}{c}R_{\mathrm{S}}=-0.439 \\
N=21 \\
\boldsymbol{p}=\mathbf{0 . 0 2 5}\end{array}$ \\
\hline $\mathrm{T}_{3}\left(\mathrm{ng} \mathrm{g}^{-1}\right)$ & $\begin{array}{c}R_{\mathrm{S}}=-0.113 \\
N=21 \\
\quad p=0.626\end{array}$ & $\begin{array}{c}R_{\mathrm{S}}=0.006 \\
N=21 \\
p=0.978\end{array}$ & $\begin{array}{c}R_{\mathrm{S}}=-0.336 \\
N=21 \\
\quad p=0.136\end{array}$ & $\begin{array}{c}R_{\mathrm{S}}=0.175 \\
N=21 \\
p=0.393\end{array}$ & $\begin{array}{l}R_{\mathrm{S}}=0.361 \\
N=21 \\
p=0.070\end{array}$ & $\begin{array}{l}R_{\mathrm{S}}=0.019 \\
N=21 \\
p=0.927\end{array}$ \\
\hline $\mathrm{T}_{4}\left(\mathrm{ng} \mathrm{g}^{-1}\right)$ & $\begin{aligned} R_{\mathrm{S}} & =-0.400 \\
N & =9 \\
p & =0.286\end{aligned}$ & $\begin{aligned} R_{\mathrm{S}}= & -0.317 \\
N & =9 \\
p & =0.406\end{aligned}$ & $\begin{aligned} R_{\mathrm{S}} & =-0.467 \\
N & =9 \\
p & =0.205\end{aligned}$ & $\begin{aligned} R_{\mathrm{S}} & =0.580 \\
N & =9 \\
\boldsymbol{p} & =\mathbf{0 . 0 4 8}\end{aligned}$ & $\begin{aligned} R_{\mathrm{S}} & =-0.098 \\
N & =9 \\
p & =0.762\end{aligned}$ & $\begin{aligned} R_{\mathrm{S}} & =0.189 \\
N & =9 \\
p & =0.557\end{aligned}$ \\
\hline $\mathrm{T}_{3} / \mathrm{T}_{4}$ & $\begin{aligned} R_{\mathrm{S}} & =-0.800 \\
N & =9 \\
\boldsymbol{p} & =\mathbf{0 . 0 1 0}\end{aligned}$ & $\begin{aligned} R_{\mathrm{S}} & =0.283 \\
N & =9 \\
p & =0.460\end{aligned}$ & $\begin{aligned} R_{\mathrm{S}} & =-0.367 \\
N & =9 \\
p & =0.332\end{aligned}$ & $\begin{aligned} R_{\mathrm{S}} & =-0.427 \\
N & =9 \\
p & =0.167\end{aligned}$ & $\begin{aligned} R_{\mathrm{S}} & =0.308 \\
N & =9 \\
p & =0.331\end{aligned}$ & $\begin{aligned} R_{S} & =0.287 \\
N & =9 \\
p & =0.366\end{aligned}$ \\
\hline
\end{tabular}

\section{Discussion}

\subsection{Contamination level}

The muscle PCB and DDT concentrations obtained in this study were higher than those reported for European sea bass from the Ria de Aveiro, Portugal (Atlantic) (Antunes and Gil, 2004) and the Orbetello Lagoon, Italy (coastal wetland) (Carubelli et al., 2007) and similar to those reported for European sea bass from Ebro Delta, Spain (western Mediterranean) (Pastor et al., 1996) (Table 3). This is in accordance with other studies who reported higher concentrations in persistent organic pollutants in the various levels of the Mediterranean marine wildlife (marine fish and mammals) compared to the levels measured in the same species in the Atlantic (Kilikidis et al., 1981; Marsili and Focardi, 1996; Canli and Atli, 2003; Fossi et al., 2004; Stefanelli et al., 2004; Storelli et al., 2004; Aguilar and Borrell, 2005; Naso et al., 2005).

It is interesting to see, contrary to other studies who report a reduction of DDT and PCB in striped dolphins of the western Mediterranean, typically used as indicators (Aguilar and Borrell, 2005), that contamination levels in sea bass remain similar to levels described 10 years ago (Pastor et al., 1996). This result underlines the importance of accuracy of such studies concerned with these pollutants and that the problem is still of interest. Most of the biological transformation processes in vertebrates metabolise small quantities of DDT into DDE. The DDE percentage is a common indicator of DDT degradation, and therefore of the age of the contaminant input (Aguilar and Borrell, 2005). Thus, this high abundance of DDE (percentage of $85 \%$ in wild sea bass) indicates a progressive degradation of the remnant DDT load and the absence of new inputs in the western Mediterranean. The exposure to DDT is likely due to the large amount of DDT that entered in the Aegean Sea as transnational pollution (through River Strymon that comes from
Table 3

Organochlorine pollutant contamination levels in muscles of European sea bass specimens (ng g ${ }^{-1}$ lipid)

\begin{tabular}{|c|c|c|c|}
\hline & Sum PCB & Sum DDT & Source \\
\hline Kavalla wild, Greece $(n=13)$ & $806 \pm 514$ & $615 \pm 348$ & This work \\
\hline $\begin{array}{l}\text { Thassos aquaculture, Greece } \\
\qquad(n=17)\end{array}$ & $487 \pm 136$ & $180 \pm 95$ & This work \\
\hline Food pellets $(n=1)$ & 140 & 29 & This work \\
\hline Ebro Delta, Spain $(n=10)$ & $800 \pm 50$ & $513 \pm 97$ & Pastor et al. (1996) \\
\hline Ria de Aveiro, Portugal $(n=10)$ & $\begin{array}{l}155 \pm 49 \text { to } \\
294 \pm 104\end{array}$ & $\begin{array}{l}108 \pm 43 \text { to } \\
336 \pm 132\end{array}$ & $\begin{array}{l}\text { Antunes and Gil } \\
(2004)^{b}\end{array}$ \\
\hline Orbetello Lagoon, Italy $(n=13)$ & $369 \pm 195$ & & $\begin{array}{l}\text { Carubelli et al. } \\
\text { (2007) }\end{array}$ \\
\hline
\end{tabular}

a PCBs (IUPAC Nos. 18, 28, 52, 49, 44, 101, 151, 149, 118, 153, 105, 138, 187, 183 $128,180,170,194)$ and DDT compounds ( $p, p^{\prime}$-DDE, $p, p^{\prime}$-DDD and $p, p^{\prime}$-DDT).

b PCBs (IUPAC Nos. 28, 52, 101, 118, 138, 153, 180) and DDT compounds ( $p, p^{\prime}-$ DDE, $p, p^{\prime}$-DDD and $\left.p, p^{\prime}-\mathrm{DDT}\right)$

F.Y.R.O.M. and Rivers Nestos and Evros that come from Bulgaria) and from the coastal areas of the Aegean Sea previous to the ban, that was applied in Greece in 1977 and in Turkey, as well to the atmospheric input from other contaminated areas (Dassenakis, 2000; Aguilar and Borrell, 2005). However in the case of Strymonikos Gulf the influence of the pollution transferred from F.Y.R.O.M. through River Strymon, seems to be the main factor as it is shown also from the higher levels of organochlorine pesticides found in Strymon River close to the border with the neighbouring country (Golfinopoulus et al., 2003).

PCBs and DDTs are known to occur in aquatic systems and fish accumulate these substances either directly from the surrounding environment or from their diet. The characteristics of organochlorinated compounds and of the aquatic environment as well as the lipid content influence also the bioaccumulation (Herbert and 
Keenleyside, 1995; Pastor et al., 1996). The wild sea bass show a significantly higher amount of pollutants in their muscles compared to the sea bass from aquaculture, especially in total PCBs and DDE lipid-normalized concentration. Whereas fresh weight concentrations reveal meanwhile that aquaculture sea bass had a significant higher concentration of the PCBs and wild sea bass showed the highest $p p^{\prime}$-DDE concentrations. The lipid proportion in the muscles of the sea bass ranged around 1-3\% of the wet weight. The observed differences in lipid content of the muscles of wild and aquaculture sea bass are certainly related to the higher lipid content of their food in the fish farm (around 10\%).The higher lipid-normalized concentrations in the wild sea bass are thus exclusively due to the low lipid percentages.

The observed variability in levels between the two sites may be related to differences in contamination of the diet. The concentrations of total PCBs (calculated as the sum of individual PCBs) in muscles of sea bass were more than the double of total DDT (calculated as the sum of $p^{\prime} p$-DDE, $p^{\prime} p$-DDD and $p^{\prime} p$-DDT). From the DDT compounds, DDE was present in the highest concentration in tissues of all the analysed organisms and fish pellets, representing $60-80 \%$ of total DDT.

The PCB patterns did not vary among wild and cultivated sea bass. The hexa- and pentachlorobiphenyls were the dominant congeners. This congeners are usually reported as dominant in marine fishes (Loizeau et al., 2001). They are the most abundant congeners in commercial PCB mixtures, such as Aroclor 1254 and 1260, which were commonly used in European countries.

Some studies have shown that food is the major contributor for PCB accumulation (Thomann and Connoly, 1984; Loizeau et al., 2001). The use of commercial diets, in fish farming and its levels of micro-contaminants, may influence pollutant concentration in cultivated fish (de Boers and Pieters, 1991). The relative distribution of PCB congeners may differ in aquatic organisms because the contamination sources have different congener patterns (Fig. 2).
The PCB congener distribution in muscles of cultured European sea bass specimens resembled that of their diet pellets, which suggest that commercial diet is their major source of PCBs in the cultured sea bass. This is marked by their low PCB concentration, especially for trichlorobiphenyls. They have a lower $\log K_{\text {ow }}$ and as consequence, they have a lower propensity to leave the aqueous environment for organic compartments. Moreover they are usually more rapidly metabolised than higher chlorinated congeners because the presence of more unsubstituted ring position on their biphenyl rings available for metabolic attack (Pastor et al., 1996). So it is possible that these compounds are lost during the processing (boiling, pressing, drying, grinding) of the whole fish (usually small pelagic fish or bycatch), which are then transformed in pellets in order to have a protein-rich meal mainly used as aquaculture feeds for carnivorous aquatic species (Antunes et al., 2007).

\subsection{Thyroid histology}

Morphologically, the fish thyroid develops basically is similar to other vertebrates (Raine et al., 2005). A minor difference is that fish do not have a compact gland, but have their thyroid tissue dispersed along the ventral aorta, which anatomically is very similar to the position of the gland in mammals. The thyroid tissue is composed of numerous follicles which contains colloid. These follicles are composed of a single layer of epithelial cells which may vary in height and form. The nucleus is spheroidal, centrally situated, poor in chromatin and contains one ore more nucleoli. The Van Gieson staining method permitted to highlight the connective tissue, but due to the lack of organisation to a distinct organ it is difficult to associate the connective tissue whether to the thyroid follicles, the capillary vessels or other neighbouring structures. The histomorphometrical analysis between the European sea bass from wild and aquaculture revealed some morphological differences (Fig. 3). The wild sea bass showed larger follicles formed by a thicker epithelium compared to the cultured sea bass. The
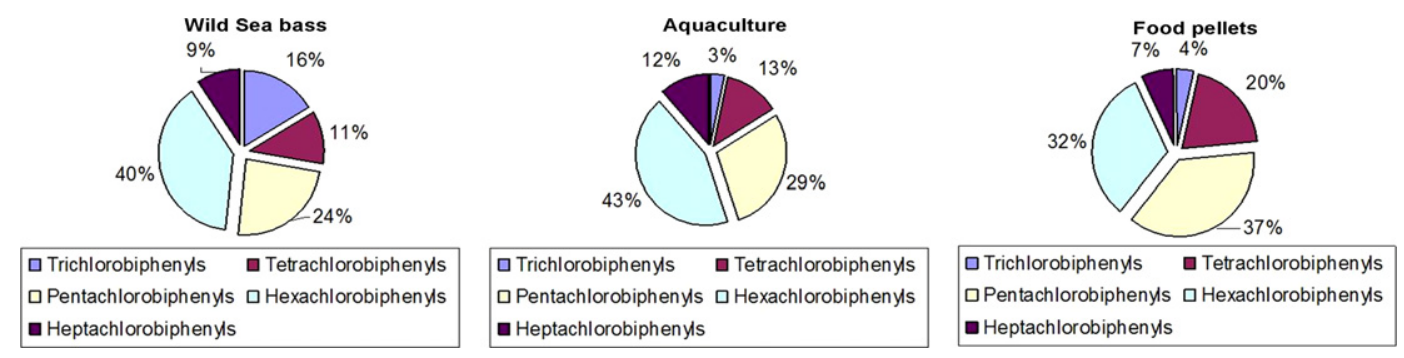

Fig. 2. Variation in the $\mathrm{PCB}$ contamination patterns.
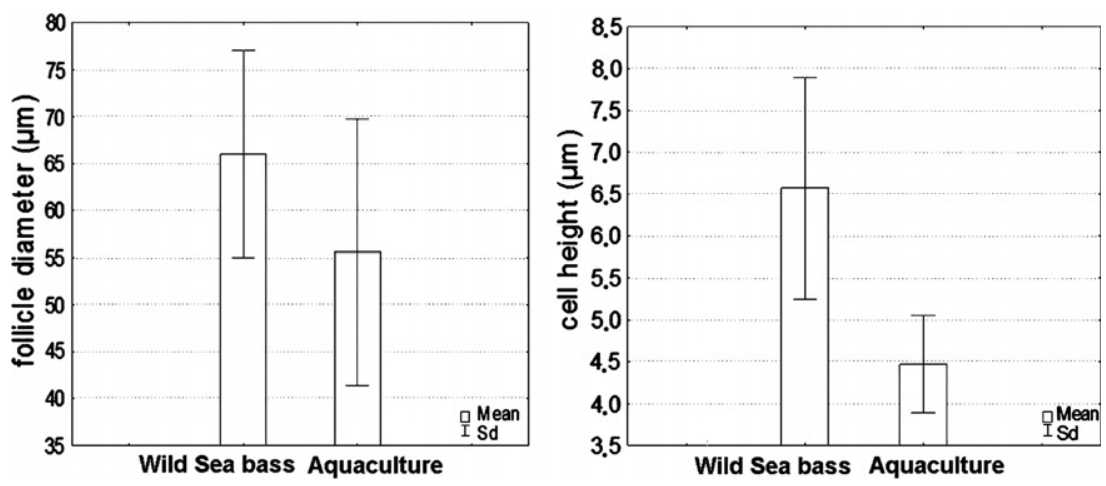

Fig. 3. Differences in thyroid morphometry (follicle diameter and epithelial cell height) in wild and aquaculture sea bass muscles. 
follicle diameters measured in sea bass are in good agreement with those described previously for fish and mammals (Zhou et al., 2000).

\subsection{Thyroid hormone level}

Muscle thyroid hormone concentration was another tested thyroid parameter. Our $\mathrm{T}_{4}$ results are comparable to other investigations of thyroid hormone concentration in eggs and larvae of other fish species but the $T_{3}$ concentrations were far below the normally encountered concentrations in eggs (Power et al., 2001). It seems that the concentrations vary among the different species. The thyroid hormones play an important role in fish embryogenesis and larval development so it is normal to find high concentrations of the biologically active form $T_{3} . T_{4}$ and $T_{3}$ detected in eggs are of maternal origin as thyroid follicles are absent from the embryo. The thyroid hormone balance in eggs probably reflects that of the maternal plasma (Power et al., 2001).

\subsection{Relationship between thyroid parameters and $P C B$ contamination}

Several studies described adverse effects of organchlorinated contaminants on the thyroid function (Brouwer et al., 1989; Schumacher et al., 1993; Hall et al., 1998; Rolland, 2000; Zhou et al., 2000; Braathen et al., 2004; Brown et al., 2004; Debier et al., 2005; Das et al., 2006; Boas et al., 2006). The most innovative aspect of our approach is the simultaneous use of two alteration endpoints. Muscle thyroid hormone concentration and histological assessment of thyroid follicles (follicle diameter and epithelial cell height) were used to gauge alterations in thyroid function.

A significant relation between mean diameter of follicles, epithelial cell height, the $\mathrm{T}_{4}$ concentration and the muscular PCBs and DDTs fresh weight concentration was observed through multivariate statistical analysis.

The follicle diameter and the epithelial cell height increases with higher PCB and DDT fresh weight concentrations (Fig. 4A). The size of the follicles and the form of the follicular cells gives an indication of the secretary activity of the gland. Thyroid gland dominated by small follicles lined by cuboidal or columnar cells can be classified as highly active. Whereas low active glands show large follicles lined by low or flattened epithelial cells (Hallgren et al., 2002). These correlations support the hypothesis that the contamination of organochlorinated compounds may induce a hyperactivity of the thyroid tissue indicated by the hypertrophy of follicular epithelial cells.

We observed an increase in $T_{4}$ concentration while the $T_{3}$ remains constant (Fig. 4B). The thyroid systems of fish and mammals are similar in many respects, with one major difference. The mammalian system is driven primarily trough the central brain-pituitary-thyroid axis that regulates thyroid secretion of both $\mathrm{T}_{4}$ and $\mathrm{T}_{3}$. In fish, the thyroid system does not appear to be driven primarily by the central brain-pituitary-thyroid axis. Instead, the central brain-pituitary-thyroid axis in fish has the primary role of ensuring $\mathrm{T}_{4}$ homeostasis. $\mathrm{T}_{3}$ production and homeostasis is regulated in peripheral tissues by conversion of $\mathrm{T}_{4}$ to $\mathrm{T}_{3}$ by deiodination (Brown et al., 2004). $T_{3}$ has been found to exert no significant feedback on TSH release.

It appears that the organochlorinated pollutants (specially the higher chlorinated PCBs and DDT metabolites) induce a hyperactivity of the thyroid follicles witch results in an increase of the $\mathrm{T}_{4}$ concentrations while the $T_{3}$ concentration, which is regulated by the deiodination in peripheral tissues, is not affected. Studies have demonstrated that massive experimental increases of $\mathrm{T}_{4}$ in fish did not increase $T_{3}$ levels, concluding that increases in $T_{4}$ do not drive $\mathrm{T}_{3}$ production (Brown et al., 2004).

The effect of PCB exposure on peripheral thyroid hormone levels is well documented in laboratory animals and wildlife. Histopathological changes of the thyroid indicative of hyperactivity were found after exposure (Hallgren et al., 2002). One of the most consistent findings is that PCB exposure disturb the levels of circulating thyroid hormones, especially $\mathrm{T}_{4}$ (Hallgren et al., 2002). In marine mammals, significant decreases of $\mathrm{T}_{3}$ and/or $\mathrm{T}_{4}$ were found in sea lions (Debier et al., 2005), polar bears (Skaare et al., 2002) and seals (Brouwer et al., 1989) and histological changes of thyroid glands related to exposure level were found in seals (Schumacher et al., 1993) and harbour porpoises (Schnitzler, 2005; Das et al., 2006). Among many different pesticides, the thyroid-disrupting effects of DDT are the most studied, DDT exposure of birds decreases $\mathrm{T}_{4}$ or increased thyroid weight and reduced colloid content of the follicles (Jefferies and French, 1969). Blubber concentration of DDT correlated negatively to $T_{3}$ in seals (Hall et al., 1998).

Similar results were observed in different fish species. Changes in thyroid histological appearance and plasma thyroid hormone levels were reported in coho salmon (Oncorhynchus kisutch) and chinook salmon (Oncorhynchus tshawytscha) collected in Great Lakes (Leatherland, 1993). Salmonids were fed by Aroclor mixtures to determine if PCBs caused these changes, but no conclusive results could be obtained (Leatherland and Sonstegard, 1978; Leatherland and Sonstegard, 1980). Given the equivocal impact of experimental exposure of PCB mixtures on trout and salmon thyroid measures, it was concluded that other factors than PCBs may cause thyroid disruption of the Great Lakes salmon (Leatherland, 1993).
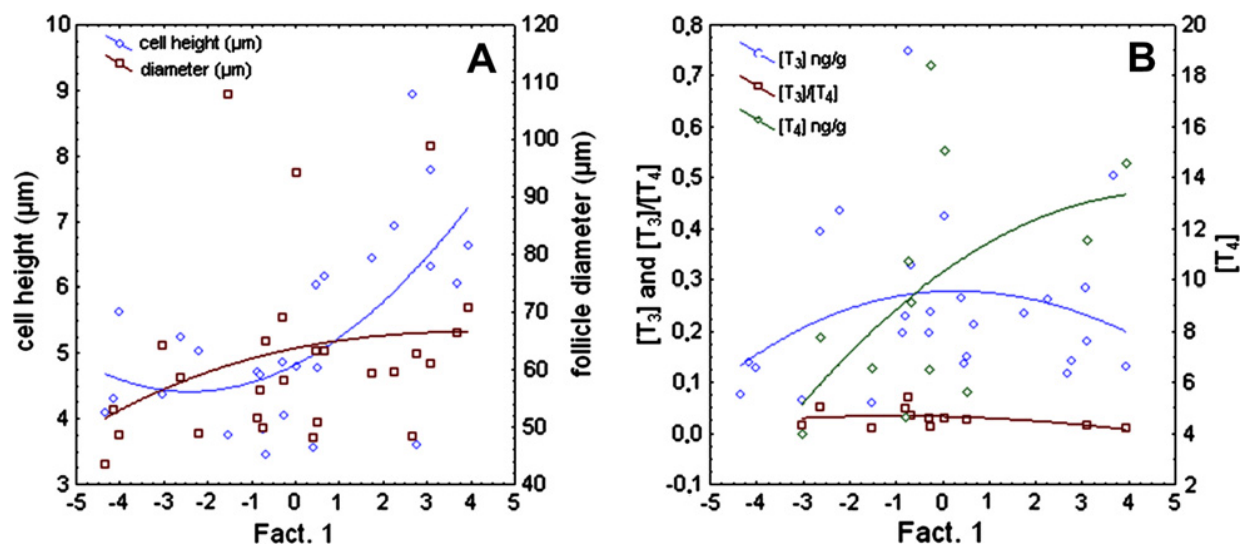

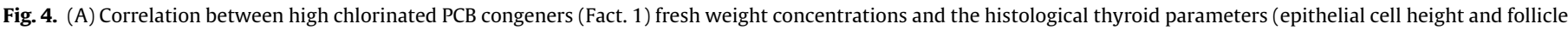
diameter). (B) Correlation between high chlorinated PCB congeners (Fact. 1) fresh weight concentrations and the muscular thyroid hormone concentrations. 
Almost all studies have reported some influence on thyroid cascade that is, therefore, a sensitive biomarker of exposure. However, the interpretation of the thyroid changes and the assessment of effect is more complex because it is difficult to distinguish between direct and indirect xenobiotic actions on the thyroid cascade, which has a considerable capacity to compensate for abuses that otherwise would disrupt thyroid hormones homeostasis. Indeed, a xenobiotic-induced change in fish thyroid function has yet to be causally linked conclusively to decreased fitness or survival (Brown et al., 2004).

\section{Acknowledgements}

Schnitzler, J. received grants from the Belgian German-speaking Community DG (Deutschsprachige Gemeinschaft) and FRIA (Fonds pour la formation à la recherche dans l'industrie et dans l'agriculture). Das, K. received grants from the FNRS (Fonds National pour la Recherche Scientifique). The authors also thank Murielle Louvet from the Laboratoire d'Ecologie animale et d'Ecotoxicologie, University of Liege (Belgium) for valuable help during the chemical analysis. MARE is the Interfacultary center for marine research of the University of Liège. This paper is a MARE publication 151.

\section{References}

Aguilar, A., Borrell, A., 2005. DDT and PCB reduction in the western Mediterranean from 1987 to 2002, as shown by levels in sriped dolphins (Stenella coerueoalba). Marine Environmental Research 59, 391-404

Antunes, P., Gil, O., 2004. PCB and DDT contamination in cultivated and wild sea bass from Ria de Aveiro, Portugal. Chemosphere 54, 1503-1507.

Antunes, P., Gil, O., Reis-Henriques, M.A., 2007. Evidence for higher biomagnification factors of lower chlorinated PCBs in cultivated sea bass. Science of the Total Environment 377, 36-44

Blanton, M.L., Specker, J.L., 2007. The hypothalamic-pituitary-thyroid (HPT) axis in fish and its role in fish development and reproduction. Critical Reviews in Toxicology 37, 97-115.

Boas, M., Feldt-Rasmussen, U., Skakkebaek, N.E., Main, K.M., 2006. Environmental chemicals and thyroid function. European Journal of Endocrinology 154, 599611.

Braathen, M., Derocher, A.E., Wiig, O., Sormo, E.G., Lie, E., Skaare, J.U., Jenssen, B.M., 2004. Relationships between PCB's and thyroid hormones and Retinol in female polar bears. Environmental Health Perspectives 112, 826-833.

Brouwer, A., Reijnders, P.J.H., Koeman, J.H., 1989. Polychlorinated biphenyl (PCB)contaminated fish induces vitamin A and thyroid hormone deficiency in the common seal (Phoca vitulina). Aquatic Toxicology 15, 99-105.

Brown, S.B., Adams, B.A., Cyr, D.G., Eales, J.G., 2004. Contaminant effects on the teleost fish thyroid. Environmental Toxicology and Chemistry 23, 1680-1701.

Canli, M., Atli, G., 2003. The relationships between heavy metal $(\mathrm{Cd}, \mathrm{Cr}, \mathrm{Cu}, \mathrm{Fe}, \mathrm{Pb}$ $\mathrm{Zn})$ levels and the size of six Mediterranean fish species. Environmenta Pollution 121, 129-136.

Carubelli, G., Fanelli, R., Mariani, G., Nichetti, S., Crosa, G., Calamari, D., Fattore, E., 2007. PCB contamination in farmed and wild sea bass (Dicentrarchus labrax L.) from a coastal wetland area in central Italy. Chemosphere 68, 1630-1635.

Collins, W.T., Capen, C.C., 1980a. Biliary excretion of ${ }^{125}$ I-Thyroxine and fine structural alterations in the thyroid of Gunn Rats fed polychlorinated biphenyls (PCB). Laboratory Investigation 43, 158-164.

Collins, W.T., Capen, C.C., 1980b. Fine structural lesions and hormonal alterations in thyroid glands of perinatal Rats exposed in Utero and by Milk to Polychlorinated Biphenyls. American Association of Pathologists 99, 125-142.

Damstra, T., Barlow, S., Bergman, A., Kavlock, R., Van Der Kraak, G., 2002. Globa Assessment of the State-of-Science of Endocrine Disruptors. International Programme on Chemical Safety.

Das, K., Vossen, A., Tolley, K., Vikingsson, G., Thron, K., Müller, G., Baumgartner, W. Siebert, U., 2006. Interfollicular fibrosis in the thyroid of the harbour porpoise: an endocrine disruption? Archives of Environmental Contamination and Toxicology 51, 720-729.

Dassenakis, M., 2000. Environmental problems of Greece from a chemical point of view. Chemistry International 22, 1-7.

de Boers, J., Pieters, H., 1991. Dietary accumulation of polychlorinated biphenyls, chlorinated pesticides and mercury in cultivated eels, Anguilla anguilla. Aquaculture and Fisheries Management 22, 329-334.

Debier, C., Ylitalo, G.M., Weise, M., Gulland, F., Costa, D.P., Le Boeuf, B.J., de Tillesse, T., Larondelle, Y., 2005. PCBs and DDT in the serum oh juvenile California sea lions: associations with vitamins $\mathrm{A}$ and $\mathrm{E}$ and thyroid hormones. Environmental Pollution 134, 323-332.

Fossi, M.C., Marsili, L., Lauriano, G., Fotrtuna, C., Canese, S., Ancora, S., Leonzio, C. Romeo, T., Merino, R., Abad, E., Jiménez, B., 2004. Assessment of toxicological status of a SW Mediterranean segment population of striped dolphin (Stenella coerulealba) using skin biopsy. Marine Environmental Research 58, 269274.

Fowles, J.R., Fairbrother, A., Trust, K.A., Kerkvliet, N.I., 1997. Effects of aroclor 1254 on the thyroid gland, immune function, and hepatic cytochrome P450 activity in Mallards. Environmental Research 75, 119-129.

Gauger, K.J., Kato, Y., Haraguchi, K., Lehmler, H.-J., Robertson, L.W., Bansal, R., Zoeller, R.T., 2004. Polybrominated Biphenyls (PCB's) exert thyroid hormonelike effects in the fetal Rat brain but do not bind to thyroid hormone receptors. Environmental Health Perspectives 112, 516-523.

Golfinopoulus, S.K., Nikolaou, A.D., Kostopoulou, M.N., Xilourgidis, N.K., Vagi, M.C., Lekkas, D.T., 2003. Organochlorine pesticides in the surface waters of Northern Greece. Chemosphere 50, 507-516.

Hall, A.J., Green, N.J.L., Jones, K.C., Pomeroy, P.P., Harwood, J., 1998. Thyroid hormones as biomarkers in grey seals. Marine Pollution Bulletin 36, 424-428.

Hallgren, S., Darnerud, P.O., 2002. Polybrominated diphenyl ethers (PBDEs), polychlorinated biphenyls (PCBs) and chlorinated paraffins (CPs) in ratstesting interactions and mechanisms for thyroid hormone effects. Toxicology $177,227-243$.

Herbert, C.E., Keenleyside, K.A., 1995. To normalize or not to normalize? Far is the question. Environmental Toxicology and Chemistry 14, 801-807.

Howdeshell, K.L., 2002. A model of the development of the brain as a construct of the thyroid system. Environmental Health Perspectives 110, 337-348.

Ishihara, A., Sawatsubashi, S., Yamauchi, K., 2003. Endocrine disrupting chemicals: interference of thyroid hormone binding to transthyretins and to thyroid hormone receptors. Molecular and Cellular Endocrinology 199, 105-117.

Janz, D.M., 2000. In: Ostrander, G.K. (Ed.), Endocrine System. The Laboratory Fish, San Diego, CA

Jefferies, D.J., French, M.C., 1969. Avian thyroid: effect of $p^{\prime} p$-DDT on size and activity. Science 166, 1278-1280.

Jenssen, G., Tyrhaug, I.B., Sormo, E.G., Andersen, O.K., 2004. Effects of PBDE-47 on thyroid and steroid hormone status in juvenile turbot (Schophtalamus maximus). Organohalogen Compounds 66, 3078-3081.

Kallianiotis, A., Koutrakis, E., Kokkinakis, A.K., 2000. Fisheries in the Kavala Prefecture. The current situation, tendencies and impacts on the prefecture's coastal areas. ÔÅRRA Coastal Zone Management Project: "Preparing an Integrated Management Plan for the Coastal Zone of the Kavala Prefecture". Development Agency of the Prefectural Administration of Kavala, pp. 1-31.

Kallianiotis, A., Vidoris, P., Sylaios, G., 2004. Fish species assemblages and geographical sub-areas in the North Aegean Sea, Greece. Fisheries Research 68, 171-187.

Kilikidis, S.D., Psomas, J.E., Kamarianos, A.P., Panetsos, A.G., 1981. Monitoring of DDT, PCBs, and other organochlorine compounds in marine organisms from the North Aegean Sea. Journal Bulletin of Environmental Contamination and Toxicology 26, 496-501.

Kobuke, L., Specker, J.L., Bern, H.A., 1987. Thyroxine content of eggs and larvae of coho salmon, Oncorhynchus kisutch. Journal of Experimental Zoology 242, 8994.

Koutrakis, E., Kokkinakis, A.K., Eleftheriadis, E.A., Argyropoulou, M.D., 2000. Seasonal changes in distribution and abundance of the fish fauna in the two estuarine systems of Strymonikos gulf (Macedonia, Greece). Belgian Journal of Zoology 130, 43-50.

Leatherland, J.F., 1993. Field observation on reproductive and developmental dysfunction in introduced and native salmonids from the Great Lakes. Histochemical Journal 19, 737-751.

Leatherland, J.F., Sonstegard, R.A., 1978. Lowering of serum thyroxine and triiodothyronine levels in yearling coho salmon by dietary mirex and PCBs. Journal of the Fisheries Research Board of Canada 35, 1285-1289.

Leatherland, J.F., Sonstegard, R.A., 1980. Effect of dietary polychloninated biphenyls (PCBs) or mirex in combination with food deprivation and testosterone administration on serum thyroid hormone concentration and bioaccumulation of organochlorines in rainbow trout, Salmo gairdneri. Journal of Fish Diseases 3, 115-124.

Loizeau, V., Abarnou, A., Cugier, P., Jaouen-Madoulet, A., Le Guellec, A.-M., Ménesguen, A., 2001. A model of PCB bioaccumulation in the seabass food web from the Seine Estuary (eastern English Channel). Marine Pollution Bulletin 43, 242-255.

Marsili, L., Focardi, S., 1996. Organochlorine levels in subcutaneous blubber biopsies of fin whales (Balaenoptera physalus) and striped dolphins (Stenella coeruleoalba) from the Mediterranean Sea. Environmental Pollution 91, 1-9.

Naso, B., Perrone, D., Ferrante, M.C., Bilacione, M., Lucisano, A., 2005. Persistent organic pollutants in edible marine species from the Gulf of Naples, Southern Italy. Science of the Total Environment 343, 83-95.

Parker, S.J., 1988. Thyroid hormone levels in Larval and Juvenile Strped Bass Morone saxatilis: Response to Changes in Salinity and Temperature. University of Rhode Island, Providence. pp. 1-147.

Pastor, D., Boix, J., Fernandez, V., Albaiges, J., 1996. Bioaccumulation of organochlorinated contaminants in three estuarine fish species (Mullus barbatus, Mugil cephalus and Dicentrarcus labrax). Marine Pollution Bulletin 32, 257-262.

Pickett, G.D., Pawson, M.G., 1994. Sea Bass-Biology, Exploitation, and Conservation. London.

Plate, E.M., Adams, B.A., Allison, W.T., Martens, G., Hawryshyn, C.W., Eales, J.G., 2002. The effects of thyroxine or a GnRH analogue on thyroid hormone deiodination in the olfactory epithelium and retina of rainbow trout, Oncorhynchus mykiss, and sockeye salmon, Oncorhynchus nerka. General and Comparative Endocrinology 127, 59-65. 
Power, D.M., Llewellyn, L., Faustino, M., Nowell, M.A., Björnsson, B.T., Einarsdottir, I.E., Canario, A.V.M., Sweeney, G.E., 2001. Thyroid hormones in growth and development of fish. Comparative Biochemistry and Physiology 130, 447-459.

Raine, J.C., 1998. Ontogeny of thyroid function in Rainbouw Trout Oncorhynchus mykiss. The University of Guelph. pp. 1-124.

Raine, J.C., Strelive, U., Leatherland, J.F., 2005. The thyroid tissue of juvenile Oncorhynchus mykiss is tubular, not follicular. Journal of Fish Biology 67, 823833.

Rolland, R.M., 2000. A review of chemically-induced alterations in thyroid and vitamin A status from field studies of wildlife and fish. Journal of Wildlife Diseases 36, 615-635.

Schnitzler, J.G., 2005. Etude histomorphométrique de la glande thyroïde du marsouin commun (Phocoena phocoena) (L.): Relation potentielle avec différents organohalogénés. Université de liège. pp. 1-50.

Scholtz, A.T., White, R.J., Koehler, V.A., Horton, S.A., 1992. Measurements of Thyroxine concentration as an indicator of the Criticalperiod for Imprinting in Kokanee Salmon (Oncorhynchus nerka): Implications for Operating Lake Roosevelt Kokanee Hatcheries. US Departement of Energy, Portland. pp. 8863, 1-96.

Schumacher, U., Zahler, S., Horny, H.-P., Heidemann, G., Skirnisson, K., Welsch, U., 1993. Histological investigations on the thyroid gland of marine mammals (Phoca vitulina, Phocoena phocoena) and the possible implication of marine pollution. Journal of Wildlife Diseases 29, 103-108.

Skaare, J.U., Larsen, H.J., Lie, E., Bernhoft, A., Derocher, A.E., Norstrom, R., Ropstad, E., Lunn, N.F., Wiig, O., 2002. Ecological risk assessment of persistent organic pollutants in the arctic. Toxicology, 193-197.
Stamatis, N., Ioannidou, D., Christoforidis, A., Koutrakis, E., 2002. Sediment pollution by heavy metals in the Strymonikos and Ierissos Gulfs, North Aegean Sea, Greece. Environmental Monitoring and Assessement 80, 33-49.

Stefanelli, P., Ausili, A., Di Muccio, A., Fossi, M.C., Di Muccio, S., Rossi, S., Colasanti, A. 2004. Organochlorine compounds in tissues of swordfish (Xiphias gladius) from Mediterranean Sea and Azores Islands. Marine Pollution Bulletin 49, 938-950.

Storelli, M.M., Storelli, A., D’Addabbo, R., Barone, G., Marcotrigiano, G.O., 2004 Polychlorinated biphenyl residues in deep-sea fish from Mediterranean Sea. Environment International 30, 343-349.

Sylaios, G., Ioannidou, D., Koutrakis, E., 1999. Water Quality Monitoring in Strymonikos Gulf and Gulf of Ierissos, Northern Greece. In: Brebbia, C.A. Anagnostopoulos, P. (Eds.), Fifth International conference on water Pollution: Modelling and Prediction, vol. 5. Wit Press, pp. 303-310.

Thomann, R.V., Connoly, J.P., 1984. Model of PCB in the lake michigan lake trou food chain. Environmental Science and Technology 18, 65-71.

Wade, M., Parent, S., Finnson, K.W., Foster, W., Younglai, E., McMahon, A., Cyr, D.G., Hughes, C., 2002. Thyroid toxicity due to subchronic exposure to a complex mixture of 16 Organochlorines, lead and cadmium. Toxicological Sciences 67 207-218.

Yamano, K., 2005. The role of thyroid hormone in fish development with reference to aquaculture. JARQ 39, 161-168.

Zhou, T., John-Alder, H.B., Weis, J.S., Weis, P., 2000. Endocrine disruption: thyroid dysfunction in mummichogs (Fundulus heteroclitus) from a polluted habitat. Marine Environmental Research 50, 393-397.

Zoeller, R.T., Tan, S.W., Tyl, R.W., 2007. General background on the hypothalamicpituitary-thyroid (HPT) axis. Critical Reviews in Toxicology 37, 11-53. 